
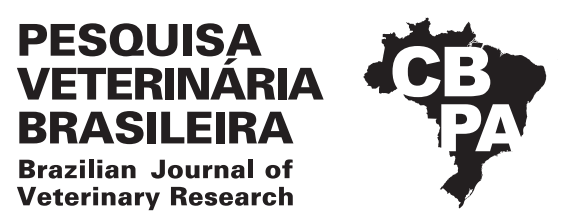

Pesq. Vet. Bras. 39(1):40-46, janeiro 2019 DOI: $10.1590 / 1678-5150-P V B-5699$

ISSN 0100-736X (Print)

ISSN 1678-5150 (Online)

\title{
Association between decreased expression of estrogen receptor alpha, androgen receptor and phosphatase and tensin homolog immunoexpression in the canine prostate $^{1}$
}

\author{
Priscila E. Kobayashi², Marcela M.P. Rodrigues ${ }^{3}$, Fatima Gartner ${ }^{4}$, Alexandra Rema ${ }^{4}$, \\ Carlos E. Fonseca-Alves ${ }^{2}$ and Renée Laufer-Amorim ${ }^{2 *}$ (D)
}

\begin{abstract}
Kobayashi P.E., Rodrigues M.M.P., Gartner F., Rema A., Fonseca-Alves C.E. \& Laufer-Amorim R. 2019. Association between decreased expression of estrogen receptor alpha, androgen receptor and phosphatase and tensin homolog immunoexpression in the canine prostate. Pesquisa Veterinária Brasileira 39(1):40-46. Departamento de Clínica Veterinária, Faculdade de Medicina Veterinária e Zootecnia, Universidade Estadual Paulista, Rua Prof. Dr. Walter Mauricio Correra s/n, Rubião Junior, Botucatu, SP 18618-970, Brazil. E-mail: renee.laufer-amorim@unesp.br

Canine prostate gland is a hormonal dependent organ and its imbalance of estrogen and androgen receptor expressions are directly associated with the development of different diseases. Due to the lack of information regarding the behavior of the aforementioned receptors in canine prostate cancer (PC), this study aimed to identify estrogen receptor alpha $(\mathrm{ER} \alpha)$, androgen receptor (AR), Ki67 and phosphatase and tensin homolog (PTEN) protein expressions in canine PC by immunohistochemistry. We found nuclear expression of ER $\alpha$ and AR in the epithelial cells of normal canine samples and a loss of protein expression in PC samples. Normal samples showed Ki67 expression in a few basal cells and the PC samples showed the highest mean of positive cells (253.1). Canine prostate cancer showed a high proliferative index, which was associated with independence of hormonal actuation. PTEN showed positive nuclear and cytoplasmic expression in normal canine samples and a loss in PC. Loss of ER $\alpha, A R$ and PTEN indicated that canine PC exhibits the same immunohistochemical phenotype as in human patients with PC resistant to hormonal therapy. Therefore, canine PC should be considered as a model to study human PC resistant to hormonal therapy.
\end{abstract}

INDEX TERMS: Estrogen receptor alpha, androgen receptor, phosphatase, tensin homolog, immunoexpression, canine prostate, dogs, prostate lesions, immunohistochemistry, hormonal receptors, PTEN.

RESUMO.- [Associação entre diminuição da expressão dos receptores de estrógeno alfa e andrógeno, e imunoexpressão de fosfatase e tensina homóloga na próstata canina.] A glândula prostática canina é um órgão dependente de hormônio, e o desequilíbrio na expressão dos receptores de estrógeno e andrógeno estão diretamente associados com

\footnotetext{
${ }^{1}$ Received on August 2, 2018.

Accepted for publication on August 29, 2018.

${ }^{2}$ Departamento de Clínica Veterinária, Faculdade de Medicina Veterinária e Zootecnia (FMVZ), Universidade Estadual Paulista (Unesp), Rua Prof. Dr. Walter Mauricio Correra s/n, Rubião Junior, Botucatu, SP 18618-970, Brazil. *Corresponding author: renee@fmvz.unesp.br

${ }^{3}$ Departamento de Anestesiologia, Faculdade de Medicina de Botucatu, Av. Prof. Montenegro s/n, Botucatu, SP 18618-687.

${ }^{4}$ Instituto de Ciências Biomédicas Abel Salazar (ICBAS), Universidade do Porto (UP), Rua Jorge de Viterbo Ferreira 228, 4050-313, Porto, Portugal.
}

o desenvolvimento de diferentes doenças. Devido à falta de informação sobre o comportamento desses receptores no câncer prostático canino (PC), este estudo tem por objetivo identificar a expressão proteica através da técnica de imuno-histoquímica do receptor de estrógeno alfa (RE $\alpha)$, receptor de andrógeno (RA), Ki67 e fosfatase e tensina homóloga (PTEN). Foi encontrado nas células epiteliais prostáticas normais caninas a expressão nuclear de RE $\alpha$ e RA, e perda de expressão proteica nas amostras de PC. As amostras normais apresentaram expressão de Ki67 em poucas células basais e as amostras de PC apresentaram a maior média de células positivas $(253,1)$. 0 câncer de próstata canino apresentou uma taxa alta de proliferação, o qual foi associado com a atuação independente de hormônio. As amostras de próstatas caninas normais revelaram marcação nuclear e citoplasmática da proteína PTEN e perda nas amostras de PC. A perda de RE $\alpha$, 
RA e PTEN indicam que as amostras de PC exibem o mesmo fenótipo imuno-histoquímico de pacientes humanos com câncer prostático resistente a terapia hormonal. Sendo assim, o PC canino deve ser considerado um modelo para estudos de câncer prostático humano resistente a terapia hormonal.

TERMOS DE INDEXAÇÃO: Estrógeno alfa, receptor andrógeno, imunoexpressão, fosfatase, tensina homóloga, próstata canina, caninos, lesões prostáticas, imuno-histoquímica, receptores hormonais, PTEN.

\section{INTRODUCTION}

Cancer is one of the most important public health concerns in the world and is the second leading cause of death (Gregory et al. 2001, Linja et al. 2001). Prostate cancer (PC) is the most prevalent cancer among men in the western world and there was a significant increase in the prevalence in the past years (Siegel et al. 2017). Hormonal receptors play a crucial role in normal prostate development and are strongly associated with the pathogenesis of human PC (Taplin et al. 1995). The most relevant hormonal receptors include the estrogen receptor (ER), and the androgen receptor (AR). The ER belongs to the nuclear receptor superfamily and is a transcriptional factor (Omoto \& Iwase 2015). There are two ER subtypes: estrogen receptor alpha (ER $\alpha)$ and estrogen receptor beta (ER $\beta$ ) (Christoforou et al. 2014). In human $\mathrm{PC}$ there is no consensus whether the ER $\alpha$ is expressed in epithelial or stromal cells and neither if its expression is directly associated to pro tumorigenic actions during cancer development (Takizawa et al. 2015). Besides, protein expression of ER $\alpha$ in human PC epithelial cells is still controversial, varying to positive in $81 \%$ cases to negative (Hobisch et al. 1997, Bonkhoff et al. 1999, Linja et al. 2003). Meanwhile, studies involving androgen independent signaling in human PC, reveal more aggressive behavior, associated with higher metastatic rates and increased resistance to treatment (Mohler et al. 2004). One of the treatments option for advanced human PC is the combination of androgen ablation and radiotherapy (Lee \& Cho 2017). This procedure has been associated with decreased morbidity, metastasis growth and increased survival time (Gregory et al. 2001).

In the PC development mutation or amplification of androgen receptor genes induce higher sensitivity of neoplastic cells to androgen and steroids hormones, produced by adrenal gland (Grossmann et al. 2001). In a late stage, tumors can become refractory to androgen deprivation and different pathways, related to cell growth and resistance to apoptosis, can be activated (Mohler et al. 2004). PI3K is one of these pathways associated with resistance to androgen deprivation (Zhang et al. 2009, Carver et al. 2011). Activation of PI3K pathway is associated with low expression of AR and PTEN (Tran et al. 2009, Carver et al. 2011).

Comparative oncology studies using dogs are a unique opportunity to evaluate spontaneous tumors in animal models beneficiating both species: humans and dogs. Dogs are the only mammal besides humans in which spontaneous PC develops with higher frequency (Palmieri et al. 2014, Fonseca-Alves et al. 2017). An important difference between both species is that dogs show higher incidence of androgen independent tumors than humans (Bryan et al. 2007). Neutered dogs have an increased risk of developing PC and they usually develop tumors from androgen independent cell (Lai et al. 2008).
In Veterinary Medicine, there are few studies describing the expression of hormonal receptors: ER $\alpha$ and AR. Additionally only two previous studies performed immunohistochemical analysis of PTEN in canine PC (Lin \& Palmieri 2016, Rivera-Calderón et al. 2016). Due to the importance of the dog as a model for human prostate cancer, this research aimed to evaluate ER, AR $\alpha$, Ki67 and PTEN expression in canine prostate cancer.

\section{MATERIALS AND METHODS}

Patients. PC samples were collected from a total of 26 adult dogs, age range from 1 to15 years-old, with no breed prediction. All included animals were intact. Inclusion criteria were based on the performance of necropsy within 30 minutes after death.

Histological analysis. Twenty-six paraffin-embedded blocks (FFPE) of prostate samples were selected from the archive of Veterinary Pathology Service, School of Veterinary Medicine and Animal Science, São Paulo State University (Unesp) and Institute of Biological Sciences Abel Salazar at the University of Porto, Portugal (ICBAS-UP). Hematoxylin and eosin (HE) stain slides were examined and histological diagnosis was established by three independent pathologists simultaneously, using a multi-head microscope. The diagnoses were made according to Fonseca-Alves et al. (2010) for benign prostatic hyperplasia (BPH) and prostatic intraepithelial neoplasia (PIN), proliferative inflammatory atrophy (PIA). Prostatic carcinomas (PC) were diagnosed according to Palmieri et al. (2014).

Five normal prostates, five BPH, three PINs, seven PIAs and six PCs were included in this study. The histopathological analysis of the six PCs revealed three tumors with acinar pattern, one tumor with solid pattern and one tumor with cribriform pattern.

Immunohistochemistry (IHC). Tissue sections $(3 \mu \mathrm{m})$ were transferred to glass slides positively charged (Fisherbrand-Color Frost $^{\mathrm{TM}}$, Fisher Scientific, Pittsburgh, Pennsylvania). Tissue samples were subjected to immunohistochemical stain using peroxidase method and DAB. Immunohistochemistry for ER and AR and Ki67 were performed at the Veterinary Pathology Service at São Paulo State University (Unesp). PTEN immunohistochemistry was performed in the Institute of Biological Sciences Abel Salazar (ICBAS), University of Porto (Portugal). Slides were dewaxed in xylol and rehydrated in graded ethanol. For the antigen retrieval, slides were incubated in a citrate buffer ( $\mathrm{pH}$ 6.0) for 30 minutes in a pressure cooker (Pascal ${ }^{\circledR}$; Dako, Carpinteria, CA). Endogenous peroxidase was neutralized by hydrogen peroxide $3 \%$ in methanol for 30 minutes. Protein block and secondary antibody incubation was performed using the Novolink Polymer (Novocastra, RE7260), according to manufacture instructions. Appropriate positive and negative controls were included for all reactions.

ER, AR and PTEN immunostaining were assessed by percentage scores of labeled cells $(0=$ absence of staining, score $1=1$ to $25 \%$ of positive cells, score $2=26$ to $50 \%$ of positive cells, score $3=51$ to $75 \%$ of positive cells, score $4=$ more than $76 \%$ of positive cells). The percentages of stained cells were evaluated in five fields at high power field (HPF) to determine the proportion of positive cells. For the evaluation of Ki67 antibody, negative and positive cells were counted in a total of 1,000 cells, from each lesion, in a 40X HPF.

Statistical analysis. The Chi-square or Fisher exact test was used to determine the association between the categorical variables for immunochemistry. Statistical analysis was performed using GraphPad Prism 5 v.5.0 (GraphPad Software Inc., La Jolla, CA). Statistical significance was defined as $\mathrm{p}<0.05$. 


\section{RESULTS}

Immunohistochemical results are summarized in Table 1. For immunohistochemical score, it was considered only expression in epithelial cells. ER presented strong nuclear expression in the epithelial, basal and some stromal cells (Fig.1A). Normal prostate and BPH tissues had greater positive ER expression when compared with PIN, PIA and PC lesions. We observed a gradual reduction of ER expression among different lesions (Table 1). PIN and PIA lesions showed decreased ER expression when compared with normal prostate $(\mathrm{p}=0.01)$ and $\mathrm{PC}$ showed lower levels of ER expression (Fig.1B) ( $p=0.02)$.

AR expression was observed in the nuclei of epithelial cells and in a few basal and stromal cells. For immunohistochemical analysis only the expression in the nuclei of epithelial cells was approached in this study. Epithelial cells showed higher expression scores in nuclei of normal epithelial cells while tumor cells had fewer cells with nuclear expression. Normal tissue and BPH showed high expression of AR (over 75\% of positive cells for all samples, Fig.1C). All pre-neoplastic lesions showed AR expression score, between 50 and $75 \%$ of positive cells. Moreover, we detected loss of AR expression in PC samples (3 samples with less than $25 \%$ of positive cells and three samples negative, Fig.1D) compared to normal, BPH and pre-neoplastic lesions.

Ki67 expression in normal prostates was found in basal cells (Fig.1E). The mean average of positive cells in normal samples was 4.6 (range of 1-7). BPH samples revealed Ki67 expression in luminal epithelial and basal cells. The mean average of positive cells was 11.8 (range of 0-29). PIN, PIA and PC samples showed positive expression in epithelial and basal cells. The PC samples (Fig.1F) presented the highest mean average (253.1 to 751 ) of positive cells. The mean average of positive cells in PIN and PIA samples were 91.3 and 70.4, respectively.

Immunohistochemical analysis of PTEN revealed nuclear and cytoplasmic expression in normal samples. Normal prostatic tissue and BPH showed high expression of PTEN (over $75 \%$ of positive cells, Fig.1G), while pre-neoplastic lesions (PIN and PIA) had decreased protein expression and PC presented loss of expression (Fig.1H).

\section{DISCUSSION}

In this study, we used canine FFPE samples and immunohistochemical technique to determine ER $\alpha$, AR, Ki67 and PTEN expression in normal prostate, $\mathrm{BPH}$, pre-neoplastic lesions and PC. Differently from our findings, ER $\alpha$ expression in humans mainly occurs in stroma of normal prostate and less frequently in androgen-independent basal cell layer (Takizawa et al. 2015, Bonkhoff 2018). In our canine samples, normal prostatic samples and BPH had high number of ER $\alpha$ positive in epithelial cells (over $50 \%$ of positive cells). Moreover, normal prostatic tissue and BPH showed higher number of ER $\alpha$ positive cells ( $>50 \%$ of positive cells) than PIN, PIA and PC. Pre-neoplastic lesions showed lower number of

Table 1. Immunohistochemistry scoring of ER, AR, Ki67 and PTEN protein expression on canine prostatic lesions

\begin{tabular}{|c|c|c|c|c|c|}
\hline Identification & Diagnosis & Estrogen receptor & Androgen receptor & PTEN & Ki67 \\
\hline Case 1 & Normal & 3 & 4 & 3 & 1 \\
\hline Case 2 & Normal & 3 & 4 & 4 & 4 \\
\hline Case 3 & Normal & 4 & 4 & 3 & 5 \\
\hline Case 4 & Normal & 3 & 4 & 4 & 6 \\
\hline Case 5 & Normal & 4 & 4 & 3 & 7 \\
\hline Case 6 & ВРH & 3 & 4 & 3 & 9 \\
\hline Case 7 & $\mathrm{BPH}$ & 3 & 4 & 4 & 0 \\
\hline Case 8 & $\mathrm{BPH}$ & 3 & 4 & 3 & 29 \\
\hline Case 9 & $\mathrm{BPH}$ & 4 & 4 & 3 & 8 \\
\hline Case 10 & $\mathrm{BPH}$ & 4 & 4 & 4 & 13 \\
\hline Case 11 & PIN & 2 & 3 & 2 & 29 \\
\hline Case 12 & PIN & 2 & 3 & 3 & 43 \\
\hline Case 13 & PIN & 2 & 3 & 2 & 202 \\
\hline Case 14 & PIA & 0 & 3 & 2 & 104 \\
\hline Case 15 & PIA & 1 & 3 & 3 & 18 \\
\hline Case 16 & PIA & 1 & 3 & 2 & 36 \\
\hline Case 17 & PIA & 2 & 3 & 1 & 68 \\
\hline Case 18 & PIA & 2 & 3 & 2 & 59 \\
\hline Case 19 & PIA & 2 & 3 & 2 & 6 \\
\hline Case 20 & PIA & 2 & 3 & 3 & 77 \\
\hline Case 21 & $\mathrm{PC}$ & 1 & 1 & 1 & 0 \\
\hline Case 22 & $\mathrm{PC}$ & 1 & 1 & 0 & 53 \\
\hline Case 23 & $\mathrm{PC}$ & 0 & 0 & 1 & 647 \\
\hline Case 24 & $\mathrm{PC}$ & 1 & 0 & 0 & 751 \\
\hline Case 25 & $\mathrm{PC}$ & 0 & 0 & 0 & 68 \\
\hline Case 26 & $\mathrm{PC}$ & 0 & 0 & 0 & 0 \\
\hline
\end{tabular}




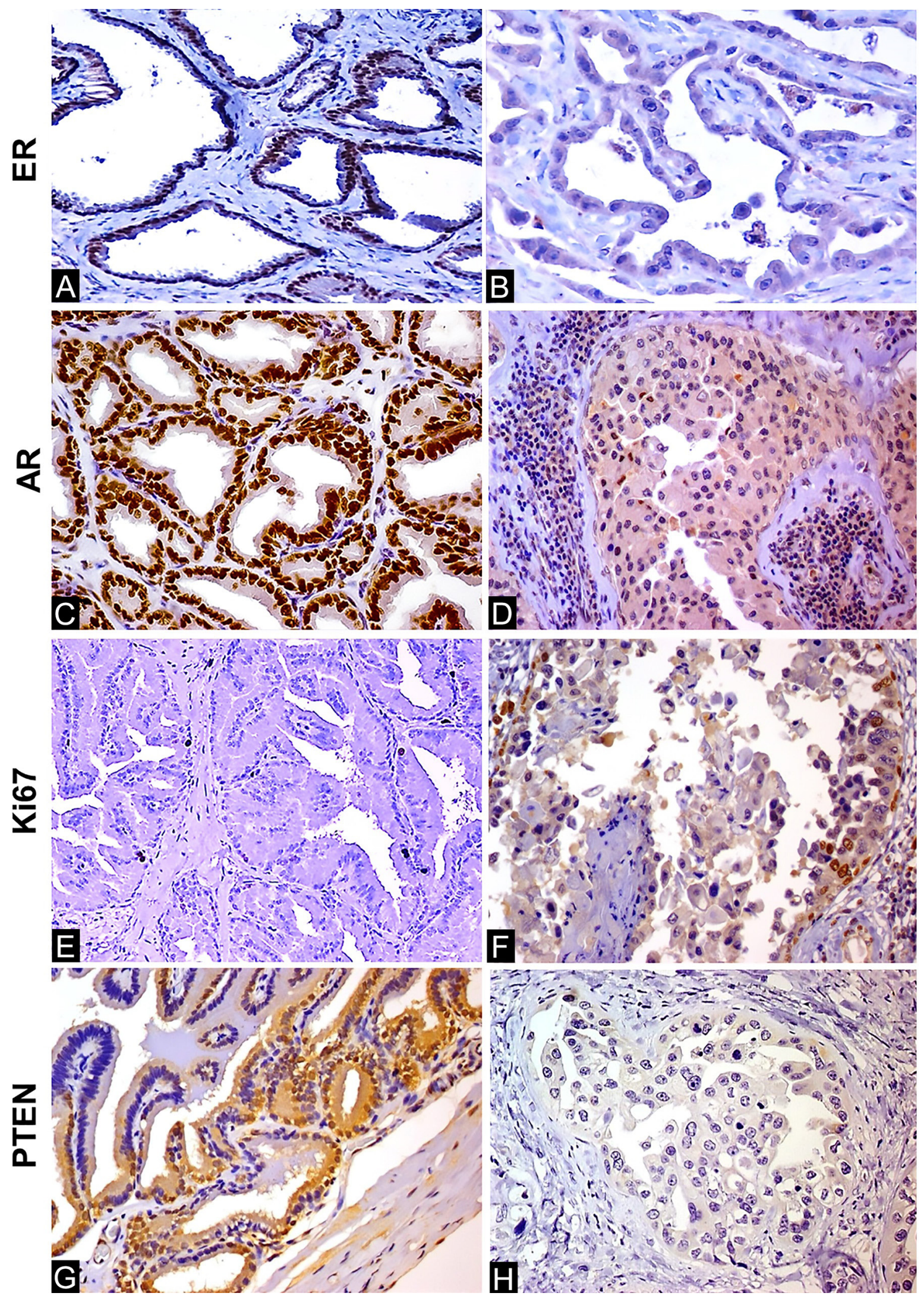

Fig.1. (A) ER $\alpha$ positive cells in BPH tissue. IHC anti-ER $\alpha$, obj.10x. (B) Loss in prostate carcinoma samples. IHC anti-ER $\alpha$, obj.40x. (C) High expression of nuclear AR staining in normal prostate. IHC anti-AR, obj.20x. (D) Loss of nuclear AR staining in prostate cancer areas (right). IHC anti-AR, obj.40x. (E) Ki67 immunostaining in basal cells of normal sample. IHC anti-Ki67, obj.10x. (F) Ki67 immunostaining increased expression in carcinoma. IHC anti-Ki67, obj.40x. (G) Normal prostatic tissue showing high expression of PTEN. IHC anti-PTEN, obj.20x. (H) Normal prostatic tissue showing loss of PTEN in PC samples. IHC anti-PTEN, obj.40x. 
positive cells ( $<50 \%$ of positive cells) and PC samples were negative or lower expression (less than $25 \%$ of positive cells). In humans there are contradictory results involving the presence or absence of ER $\alpha$ in PC. However, the absence of ER $\alpha$ in human PC cell lines and PC metastases is usually described in patients with distant metastasis who have failed endocrine therapy (Hobisch et al. 1997, Takizawa et al. 2015). The ER methylation in human PC cell lines and prostate cancer tissues were observed and associated with tumor pathological grades, suggesting a mechanism of ER gene inactivation and consequently downregulation of ER protein in PC (Li et al. 2000). These results indicate that PC becomes independent of ER $\alpha$ expression, suggesting a more aggressive and unresponsive behavior towards anti-estrogens treatments.

Previous researches evaluating AR expression in canine prostate cancer showed cytoplasmic localization (Lai et al. 2009, Akter et al. 2015). However, as a nuclear receptor, its role is mainly nuclear to control transcription of specific genes (Tan et al. 2015). We found AR nuclear expression in all prostatic lesions and occasional cytoplasmic expression, but we only considered the nuclear staining. Normal prostatic tissue and BPH showed higher levels of AR expression $(100 \%$ of positive cells) and PIA and PIN lesions had moderate staining of AR ( 50 to $75 \%$ of positive cells). Four cases of PC were negative for AR and two tumors showed lower expression (less than $25 \%$ of positive cells).

In Veterinary Medicine, there are few studies evaluating the expression of hormonal receptors in canine prostate samples using different methodologies and analysis (Jiang et al. 2005, Grieco et al. 2006, Gallardo et al. 2007). Additionally, comparative oncology studies between human and canine methodology standardization is required. We believe that canine carcinogenic process is similar to humans, although dogs show some particularities related with genetic alterations and protein localization (Alves et al. 2014).

Human PC shows multifactorial etiology such as diet, race, gene alterations and hormones. Estrogens and androgens hormones play essential role in cellular growth and differentiation control of normal prostatic tissue (Cooney 2017). Previous epidemiological and experimental results suggested a relationship among estrogen levels, PC carcinogenesis and cancer progression (Asgari \& Morakabati 2011). Neutered dogs show higher risk of PC development and more aggressive histological subtypes when compared to humans (Teske et al. 2002, Bryan et al. 2007). Thus, is a hypothesis that canine PC shows local aggressive behavior, high metastatic rate and unresponsive to chemotherapy and radiotherapy (Gallardo et al. 2007). Our results of loss of $\mathrm{ER} \alpha$ and AR immunohistochemical expression in canine PC indicate that hormone-based therapies (such as tamoxifen or androgen ablation) is not an optimal therapy for dogs. Therefore, dogs are a unique model to study drug response associated to hormonal independent PCs.

We found none immunohistochemical staining of Ki67 in three prostatic samples (one BPH and two PC). In these samples, we did not detect positive internal control, so these cases were not included for Ki67. One PC sample negative to Ki67 was positive to AR and PTEN and the other one was positive to ER $\alpha$, AR and PTEN indicating that the Ki67 protein is most sensitive to fixation time. PC showed higher proliferative index when compared to normal, $\mathrm{BPH}$ and preneoplastic lesions.

Ki67, a nuclear based protein and proliferation marker, is reported as predictive factor of human PC progression (Tollefson et al. 2014, Ma et al. 2018). Our study confirmed previous findings demonstrating association between high Ki67 index and canine PC (Rodrigues et al. 2013, Fonseca-Alves et al. 2017). However, further studies are necessary to determine the role of Ki67 as a predictive marker in canine PC.

Our previous results evaluating copy number abnormalities (CGH) in canine prostatic lesions showed loss of $A R$ and PTEN genes in $21,5 \%$ of canine PC (unpublished data). This previous result associated with our immunohistochemical data show a strong indication that AR loss play important role in PC development.

PTEN is a tumor suppressor gene and controls PI3K signaling pathway (Carver et al. 2011). PI3K pathway is associated with AR nuclear signaling and human studies had shown loss of AR and PTEN in PC (Scher \& Sawyers 2005). These findings demonstrate the independence of androgen signaling for cell proliferation associated with activation of PI3K pathway in human PC subject to androgen deprivation therapy. No previous research evaluated PTEN immunohistochemical expression in canine prostate cancer. We found strong nuclear and low cytoplasmic staining of PTEN in normal canine and BPH samples ( $>50 \%$ of positive cells) and loss of nuclear staining in all PC samples in which only two PC had also shown weak cytoplasmic expression.

We believe that high proliferative index of canine PC may be associated with ER $\alpha$, AR and PTEN losses, which are important proteins related to cell proliferation and differentiation control in canine PC and mediate the independence of hormonal stimulation for tumor initiation (Amorim et al. 2014).

\section{CONCLUSIONS}

Canine prostate cancer shows high proliferative index and is associated with independence of hormonal action.

Loss of ER $\alpha$, AR and PTEN in canine PC exhibits the same immunohistochemical phenotype of human patients with PC resistant to hormonal therapy.

Expression of Ki67 was significantly up regulated in malignant lesions compared to normal, BPH and pre neoplastic lesions associated with prostate cancer progression.

Canine PC should be considered as an interesting model to study human prostate cancer resistant to hormonal therapy.

Acknowledgements.- The authors are grateful to São Paulo Research Foundation (\#2006/06523-1 and \#2012/16068-0) for financial support of this study.

Conflict of interest.- None of the authors have any financial or personal relationship that could inappropriately influence or bias the content of the paper.

\section{REFERENCES}

Akter S.H., Lean F.Z., Lu J., Grieco V. \& Palmieri C. 2015. Different growth patterns of canine prostatic carcinoma suggests different models of tumor-initiating cells. Vet. Pathol. 52(6):1027-1033. <http://dx.doi. org/10.1177/0300985815574008><PMid:25755134> 
Alves C.E.F., Busso A.F., Silveira S.M., Rogatto S.R. \& Amorim R.L. 2014. Abstract 5260: genomic gains in prostatic carcinoma and proliferative inflammatory atrophy in dogs. Cancer Res. 72(8):5260.

Amorim R.L., Fonseca-Alves C.E., Calderon L.G., Justo A.A. \& Rogatto S.R. 2014. Abstract 83: increased cyclooxygenase- 2 and vascular endothelial growth factor protein expression is associated with canine prostatic carcionogenesis process. Cancer Res. 74(19):83. <http://dx.doi.org/10.1158/1538-7445. AM2014-83>

Asgari M. \& Morakabati A. 2011. Estrogen receptor beta expression in prostate adenocarcinoma. Diagn. Pathol.6(1):61. <http://dx.doi.org/10.1186/17461596-6-61><PMid:21733187>

Bonkhoff H. 2018. Estrogen receptor signaling in prostate cancer: implications for carcinogenesis and tumor progression. Prostate 78(1):1-9. <http:// dx.doi.org/10.1002/pros.23446> <PMid:29094395>

Bonkhoff H., Fixemer T., Hunsicker I. \& Remberger K. 1999. Estrogen receptor expression in prostate cancer and premalignant prostatic lesions. Am. J. Pathol. 155(2):641-647.<http://dx.doi.org/10.1016/S0002-9440(10)651607> <PMid:10433957>

Bryan J.N., Keeler M.R., Henry C.J., Bryan M.E., Hahn A.W. \& Caldwell C.W. 2007. A population study of neutering status as a risk factor for canine prostate cancer. Prostate 67(11):1174-1181.<http://dx.doi.org/10.1002/ pros.20590><PMid:17516571>

Carver B.S., Chapinski C., Wongvipat J., Hieronymus H., Chen Y., Chandarlapaty S., Arora V.K., Le C., Koutcher J., Scher H., Scardino P.T., Rosen N. \& Sawyers C.L. 2011. Reciprocal feedback regulation of PI3K and androgen receptor signaling in PTEN-deficient prostate cancer. Cancer Cell 19(5):575-586. <http://dx.doi.org/10.1016/j.ccr.2011.04.008> <PMid:21575859>

Christoforou P., Christopoulos P.F. \& Koutsilieris M. 2014. The role of estrogen receptor $\beta$ in prostate cancer. Mol. Med. 20(1):427-434. <http://dx.doi. org/10.2119/molmed.2014.00105 > <PMid:25032955>

Cooney K.A. 2017. Inherited predisposition to prostate cancer: from gene discovery to clinical impact. Trans. Am. Clin. Climatol. Assoc. 128:14-23. <PMid:28790484>

Fonseca Alves C.E., Faleiro M.B.R., Laufer Amorim R. \& Moura V.M.B.D. 2010. Avaliação histológica da próstata de cães adultos sexualmente intactos. Arq. Bras. Med. Vet. Zootec. 62(3):596-602. <http://dx.doi.org/10.1590/ S0102-09352010000300014>

Fonseca-Alves C.E., Kobayashi P.E., Palmieri C. \& Laufer-Amorim R. 2017. Investigation of c-KIT and Ki67 expression in normal, preneoplastic and neoplastic canine prostate. BMC Vet. Res. 13(1):380. <http://dx.doi. org/10.1186/s12917-017-1304-0><PMid:29207991>

Gallardo F., Mogas T., Baró T., Rabanal R., Morote J., Abal M., Reventós J. \& Lloreta J. 2007. Expression of androgen, oestrogen alpha and beta, and progesterone receptors in the canine prostate: differences between normal, inflamed, hyperplastic and neoplastic glands. J. Comp. Pathol. 136(1):18. <http://dx.doi.org/10.1016/j.jcpa.2006.08.007> <PMid:17078963>

Gregory C.W., He B., Johnson R.T., Ford O.H., Mohler J.L., French F.S. \& Wilson E.M. 2001. A mechanism for androgen receptor-mediated prostate cancer recurrence after androgen deprivation therapy. Cancer Res. 61(11):43154319. <PMid:11389051>

Grieco V., Riccardi E., Rondena M., Romussi S., Stefanello D. \& Finazzi M. 2006. The distribution of oestrogen receptors in normal, hyperplastic and neoplastic canine prostate, as demonstrated immunohistochemically. J. Comp. Pathol. 135(1):11-16. <http://dx.doi.org/10.1016/j.jcpa.2006.02.005> <PMid:16815431>

Grossmann M.E., Huang H. \& Tindall D.J. 2001. Androgen receptor signaling in androgen-refractory prostate cancer. J. Natl Cancer Inst. 93(22):16871697. <http://dx.doi.org/10.1093/jnci/93.22.1687><PMid:11717329>

Hobisch A., Hittmair A., Daxenbichler G., Wille S., Radmayr C., HobischHagen P., Bartsch G., Klocker H. \& Culig Z. 1997. Metastatic lesions from prostate cancer do not express oestrogen and progesterone receptors.
J. Pathol. 182(3):356-361. <http://dx.doi.org/10.1002/(SICI)10969896(199707)182:3<356::AID-PATH863>3.0.CO;2-U><PMid:9349240>

Jiang J., Chang H.L., Sugimoto Y. \& Lin Y.C. 2005. Effects of age on growth and ERbeta mRNA expression of canine prostatic cells. Anticancer Res. 25(6B):4081-4090. <PMid:16312047>

Lai C.L., Van den Ham R., Mol J. \& Teske E. 2009. Immunostaining of the androgen receptor and sequence analysis of its DNA-binding domain in canine prostate cancer. Vet. J. 181(3):256-260. <http://dx.doi.org/10.1016/j. tvjl.2008.04.009><PMid:18583166>

Lai C.L., L’Eplattenier H., van den Ham R., Verseijden F., Jagtenberg A., Mol J.A. \& Teske E. 2008. Androgen receptor CAG repeat polymorphisms in canine prostate cancer. J. Vet. Intern. Med.22(6):1380-1384.<http://dx.doi org/10.1111/j.1939-1676.2008.0181.x><PMid:18783352>

Lee S.U. \& Cho K.H. 2017. Multimodal therapy for locally advanced prostate cancer: the roles of radiotherapy, androgen deprivation therapy, and their combination. Radiation Oncol. J. 35(3):189-197. <http://dx.doi org/10.3857/roj.2017.00318><PMid:29037021>

Li L.C., Chui R., Nakajima K., Oh B.R., Au H.C. \& Dahiya R. 2000. Frequent methylation of estrogen receptor in prostate cancer: correlation with tumor progression. Cancer Res. 60(3):702-706. <PMid:10676656>

Lin H.Y. \& Palmieri C. 2016. Is STAT3 and PTEN expression altered in canine prostate cancer? J. Comp. Pathol. 155(2/3):185-189. <http://dx.doi. org/10.1016/j.jcpa.2016.05.016> <PMid:27401955>

Linja M.J., Savinainen K.J., Tammela T.L., Isola J.J. \& Visakorpi T. 2003. Expression of ER $\alpha$ and ER $\beta$ in prostate cancer. Prostate 55(3):180-186. <http://dx.doi.org/10.1002/pros.10242> <PMid:12692783>

Linja M.J., Savinainen K.J., Saramäki O.R., Tammela T.L., Vessella R.L. \& Visakorpi T. 2001. Amplification and overexpression of androgen receptor gene in hormone-refractory prostate cancer. Cancer Res. 61(9):3550-3555. <PMid:11325816>

Ma T., Yang S., Jing H., Cong L., Cao Z., Liu Z. \& Huang Z. 2018. Apparent diffusion coefficients in prostate cancer: correlation with molecular markers Ki-67, HIF- $1 \alpha$ and VEGF. NMR Biomed. 31(3):3884. <http://dx.doi.org/10.1002/ nbm.3884><PMid:29315957>

Mohler J.L., Gregory C.W., Ford 3rd O.H., Kim D., Weaver C.M., Petrusz P., Wilson E.M. \& French F.S. 2004. The androgen axis in recurrent prostate cancer. Clin. Cancer Res. 10(2):440-448. <http://dx.doi.org/10.1158/1078-0432. CCR-1146-03> <PMid:14760063>

Omoto Y. \& Iwase H. 2015. Clinical significance of estrogen receptor $\beta$ in breast and prostate cancer from biological aspects. Cancer Sci. 106(4):337-343. <http://dx.doi.org/10.1111/cas.12613><PMid:25611678>

Palmieri C., Lean F.Z., Akter S.H., Romussi S. \& Grieco V. 2014. A restrospective analysis of 111 canine prostatic samples: Histopathological findings and classification. Res. Vet. Sci. 97(3):568-573. <http://dx.doi.org/10.1016/j. rvsc.2014.11.006> <PMid:25468798>

Rivera-Calderón L.G., Fonseca-Alves C.E., Kobayashi P.E., Carvalho M., Drigo S.A., Oliveira Vasconcelos R. \& Laufer-Amorim R. 2016. Alterations in PTEN, MDM2, TP53 and AR protein and gene expression are associated with canine prostate carcinogenesis. Res. Vet. Sci. 106:56-61. <http://dx.doi. org/10.1016/j.rvsc.2016.03.008><PMid:27234536>

Rodrigues M.M., Rema A., Gartner M.F. \& Laufer-Amorim R. 2013. Role of adhesion molecules and proliferation hyperplasic, pre neoplastic and neoplastic lesions in canine prostate. Pakistan J. Biol. Sci.16(21):1324-1329. <http://dx.doi.org/10.3923/pjbs.2013.1324.1329><PMid:24511741>

Scher H.I. \& Sawyers C.L. 2005. Biology of progressive, castration-resistant prostate cancer: directed therapies targeting the androgen-receptor signaling axis. J. Clin. Oncol. 23(32):8253-8261. <http://dx.doi.org/10.1200/ JC0.2005.03.4777><PMid:16278481>

Siegel R.L., Miller K.D. \& Jemal A. 2017. Cancer statistics, 2017. CA, Cancer J. Clinicians 67(1):7-30. <http://dx.doi.org/10.3322/caac.21387> $<$ PMid:28055103> 
Takizawa I., Lawrence M.G., Balanathan P., Rebello R., Pearson H.B., Garg E., Pedersen J., Pouliot N., Nadon R., Watt M.J., Taylor R.A., Humbert P., Topisirovic I., Larsson O., Risbridger G.P. \& Furic L. 2015. Estrogen receptor alpha drives proliferation in PTEN-deficient prostate carcinoma by stimulating survival signaling, MYC expression and altering glucose sensitivity. Oncotarget 6(2):604-616. <http://dx.doi.org/10.18632/ oncotarget.2820><PMid:25436982>

Tan M.H., Li J., Xu H.E., Melcher K. \& Yong E. 2015. Androgen receptor: structure, role in prostate cancer and drug discovery. Acta Pharmacol. Sinica 36(1):3-23. <http://dx.doi.org/10.1038/aps.2014.18><PMid:24909511>

Taplin M.E., Bubley G.J., Shuster T.D., Frantz M.E., Spooner A.E., Ogata G.K., Keer H.N. \& Balk S.P. 1995. Mutation of the androgen-receptor gene in metastatic androgen-independent prostate cancer. N. Engl. J. Med. 332(21):1393-1398. <http://dx.doi.org/10.1056/NEJM199505253322101><PMid:7723794>

Teske E., Naan E.C., van Dijk E.M., Van Garderen E. \& Schalken J.A. 2002. Canine prostate carcinoma: epidemiological evidence of an increased risk in castrated dogs. Mol. Cell. Endocrinol. 197(1-2):251-255. <http://dx.doi. org/10.1016/S0303-7207(02)00261-7><PMid:12431819>
Tollefson M.K., Karnes R.J., Kwon E.D., Lohse C.M., Rangel L.J., Mynderse L.A., Cheville J.C. \& Sebo T.J. 2014. Prostate cancer Ki-67 (MIB-1) expression, perineural invasion, and gleason score as biopsy-based predictors of prostate cancer mortality: the mayo model. Mayo Clin. Proc. 89(3):308-318. <http://dx.doi.org/10.1016/j.mayocp.2013.12.001> <PMid:24486077>

Tran C., Ouk S., Clegg N.J., Chen Y., Watson P.A., Arora V., Wongvipat J., Smith-Jones P.M., Yoo D., Kwon A., Wasielewska T., Welsbie D., Chen C.D., Higano C.S., Beer T.M., Hung D.T., Scher H.I., Jung M.E. \& Sawyers C.L. 2009. Development of a second-generation antiandrogen for treatment of advanced prostate cancer. Science 324(5928):787-790. <http://dx.doi. org/10.1126/science.1168175> <PMid:19359544>

Zhang W., Zhu J., Efferson C.L., Ware C., Tammam J., Angagaw M., Laskey J., Bettano K.A., Kasibhatla S., Reilly J.F., Sur C. \& Majumder P.K. 2009. Inhibition of tumor growth progression by antiandrogens and mTOR inhibitor in a Pten-deficient mouse model of prostate cancer. Cancer Res. 69(18):7466-7472. <http://dx.doi.org/10.1158/0008-5472.CAN-084385> <PMid:19738074> 